\title{
ROLE OF ARTERIAL BLOOD GAS (ABG) AS A VALUABLE ASSESSMENT TOOL OF DISEASE SEVERITY IN SARS-COV-2 PATIENTS
}

\author{
ULOGA ARTERIJSKIH GASOVA KRVI (AGK) KAO VREDNOG PARAMETRA \\ ZA PROCENU TEŽINE OBOLJENJA U SARS-COV-2 PACIJENATA
}

\author{
Jyot Amrita ${ }^{1}$, ArvinderPal Singh ${ }^{2}$ \\ ${ }^{1}$ Department of Biochemistry, Sri Guru Ram Das University of Health Sciences, Amritsar, Punjab, India \\ ${ }^{2}$ Department of Anesthesia, Sri Guru Ram Das University of Health Sciences, Amritsar, Punjab, India
}

\section{Summary}

Background: COVID-19 is caused by a novel coronavirus, named severe acute respiratory syndrome coronavirus 2 (SARS-CoV-2). The foremost predominant complication of SARS-CoV-2 is arterial hypoxemia thereby disturbing lung compliance, requiring mechanical ventilation.

The aim of the current research study is to analyze role of $A B G$ as a valuable assessment tool of disease severity in SARS-CoV-2 patients.

Methods: 170 arterial blood samples were collected from patients admitted in Intensive Care Unit (ICU) of Sri Guru Ram Das Charitable Hospital, Amritsar. They were analyzed for arterial blood gas using $A B G$ analyzer. Parameters of $\mathrm{ABG}$ such as $\mathrm{pH}, \mathrm{pCO}_{2}, \mathrm{HCO}_{3}, \mathrm{O}_{2}$ saturation, ionized calcium ( $\mathrm{iCa}$ ) and calculated ionized calcium (at $\mathrm{pH}$ 7.4) was calculated for all the samples.

Results: Continuous variables were described as medians with interquartile ranges (IQRs) and categorical variables as percentages and frequencies. Spearman correlation test was done for calculation of correlation between $\mathrm{pH}$ and other ABG parameters. Analysis of arterial blood gas revealed significant negative correlation $(\mathrm{p}<0.05)$ between $\mathrm{pH}$ and $\mathrm{pCO}_{2}$ and significant positive correlation $(\mathrm{p}<0.05)$ between $\mathrm{pH}$ and $\mathrm{HCO}_{3}$ and between $\mathrm{pH}$ and delta ionized calcium. Low levels (98.2\%) of ionized calcium were observed while monitoring the $A B G$ findings though weak negative correlation $(\mathrm{p}<0.05)$ was observed between $\mathrm{pH}$ and $\mathrm{iCa}$.

Conclusions: Our study suggests that ABG analysis acts as a momentous indicator for critically ill patients admitted in Intensive Care Unit (ICU). Estimation of $\mathrm{iCa}$ in this critical

\section{Kratak sadržaj}

Uvod: COVID-19 je izazvan novim koronavirusom koji izaziva težak respiratorni sindrom koronavirus 2 (SARS-CoV-2). Predominantna komplikacija SARS-CoV-2 je arterijska hipoksemija koja dovodi do oštećenja pluća i zahteva mehaničku ventilaciju. Svrha ovog izučavanja je da analizira ulogu AGK kao vrednog parametra za procenu težine oboljenja kod SARS-CoV-2 pacijenata.

Metode: Uzeto je 170 arterijskih uzoraka krvi od pacijenata koji su bili primljeni u Intenzivnu jedinicu (ICU) u Sri Guru Ram Das Charitable Hospital, Amristar. Analizirani su arterijski gasovi krvi primenom $A B G$ analizatora. Parametri $A B G$ (AGK) bili su $\mathrm{pH}, \mathrm{pCO}_{2}, \mathrm{HCO}_{3}, \mathrm{O}_{2}$ saturacija, jonizovani kalcijum (iCA) i izračunati jonizovani kalcijum (na pH 7,4) za sve analizirane uzorke.

Rezultati: Za sve promenljive parametre izračunata je medijana i interkvartilne oblasti (IQRs) i varijable kako što su procenti i frekvencije. Korišćen je Spearman korelacioni test za izračunavanje korelacije između $\mathrm{pH}$ i i drigih ABG parametara. Analizom arterijskih gasova krvi dobijena je značajna negativna korelacija $(\mathrm{p}<0,05)$ između $\mathrm{pH}$ i $\mathrm{pCO}_{2}$ i značajna pozitivna korelacija $(p<0,05)$ između $\mathrm{pH} \mathrm{i} \mathrm{HCO}_{3}$ i između $\mathrm{pH}$ i delta jonizovanog kalcijuma. Niski nivoi $(98,2 \%)$ jonizovanog kalcijuma su nađeni pri praćenju ABG nalaza u toku nedeljne negativne korelacije $(p<0,05)$ kad je praćena između $\mathrm{pH}$ i iCa.

Zaključak: Naše izučavanje ukazuje da ABG analiza ima ulogu trenutnog indikatora za kritično bolesne pacijente primljene u Intenzivnu Jedinicu (ICU). Određivanje iCa u ovom kritičnom momentui ima veoma značajnu ulogu u

Address for correspondence:

Dr. Jyot Amrita PhD

Department of Biochemistry

Sri Guru Ram Das Institute of Medical Sciences and Research

Amritsar-143001, Punjab, India

(M) 094171-07517

e-mail: jyotamrita@yahoo.com 
care setting acts as a distinctive biochemical feature of SARS-CoV-2 disease, as an initial assessment tool, for hypocalcemia.

Keywords: arterial blood gas, SARS-CoV-2, ionized calcium, hypocalcemia

\section{Introduction}

The outbreak of Novel coronavirus disease (COVID-19) was initially noticed in a seafood market in Wuhan city in Hubei Province in Mid-December, 2019 and subsequently speeded to 214 countries worldwide (1). World Health Organization (WHO) declared this outbreak as a »Public Health Emergency of International Concern (PHEIC) on $30^{\text {th }}$ January, 2020 and later declared COVID-19 as pandemic on $11^{\text {th }}$ March, 2020 (2).

The novel coronavirus belongs to lineage $B$ of the genus beta - coronavirus of the coronavirus family which includes SARS-CoV (Severe Acute Respiratory syndrome) and MERS - CoV (Middle East Respiratory Syndrome) (3). The seventh member of the corona virus family to infect humans is 2019 novel coronavirus (2019-nCoV) (4). Coronaviruses (CoVs) are positive sense single stranded RNA viruses of the family coronaviridae that infect a wide host range to produce disease ranging from common cold to severe illness (5).

SARS-CoV2 affects different people in various ways. Most infected people develop mild to moderate illness and may recover without hospitalization. Primarily transmitted through the respiratory tract, the most common clinical presentations of symptomatic individuals infected with SARS-CoV-2 include fever, dyspnea, cough, fatigue, and sore throat. In advanced cases, patients may rapidly develop respiratory failure with acute respiratory distress syndrome, and even progress to death (6).

The foremost predominant complication of SARS-CoV-2 is arterial hypoxemia thereby disturbing lung compliance requiring mechanical ventilation. Arterial blood gas (ABG) analysis provides information regarding patient oxygenation, ventilation adequacy and acid base levels.

Or in other words we can say, it tells the activity in both respiratory system and metabolic system. Both the systems work together in order to maintain the $\mathrm{pH}$ in normal range. If one system is disturbed the other will try to compensate. Thus, the current research was aimed to analyze the role of $A B G$ as a valuable assessment tool of disease severity in SARSCoV2 patients. We also hypothesized that which parameter among $A B G$ analysis can play a significant role and to what extent as regards to disease severity. praćenju SARS CoV-2 oboljenja kao inicijalno sredstvo ispitivanja hipokalcijemije.

Ključne reči: arterijski gasovi krvi, SARS-CoV-2, jonizovani kalcijum, hipokalcijemija

\section{Material and Methods}

\section{Participants}

In the present observational study 170 samples of $A B G$ were collected from 17 critically ill patients severely affected with the disease and admitted in Intensive Care Unit (ICU) of Sri Guru Ram Das Charitable Hospital, Amritsar, Punjab (India) during the period from October 2020 to December 2020. They were laboratory confirmed tested positive cases for corona virus. The diagnosis was established by reverse-transcriptase polymerase chain reaction (RTPCR) method by testing nasal and pharyngeal swab specimens according to World Health Organization (WHO) interim guidance criteria. Hematology testing was conducted on H560 Hematology analyzer (Erba Mannheim). Analysis of $A B G$ was done on $A B G$ analyzer (Siemens make) in clinical laboratory of the hospital for arterial samples of all admitted patients whose stay was more than 5 days. The clinical outcome was monitored until the discharge of the patient. No written informed consent of patient was required as the study included only undisclosed information. The study was approved by the institutional ethics committee.

Before proceeding with the analysis, the preanalytical errors were taken into consideration to avoid false results for $\mathrm{pH}$ and ionized calcium (iCa). To achieve correct heparin and blood concentration correct blood volume of sample was collected with immediate mixing after sampling to avoid false low levels of iCa. After collection of the sample the blood was immediately analyzed in the clinical laboratory for ABG (within 20 minutes) to avoid any discrepancy in the results because loss of $\mathrm{pCO}_{2}$ from the collected sample may increase $\mathrm{pH}$ as alkaline $\mathrm{pH}$ increases protein bound calcium and decreases iCa levels. On the other hand acidic $\mathrm{pH}$ decreases protein bound calcium and increases iCa levels. Even haemolysis results in false levels of low ionized calcium.

Among the $\mathrm{ABG}$ parameters $\mathrm{pH}, \mathrm{pCO}_{2}, \mathrm{HCO}_{3}$ and ionized calcium ( $\mathrm{iCa}$ ) were mainly taken into consideration. Ionized calcium levels were calculated both as actually measured levels and corrected mathematically at $\mathrm{pH} 7.4$ to avoid influence of sample handling. Delta ionized calcium was also calculated to move towards more accuracy. 
Calculation of corrected ionized calcium (at $\mathrm{pH}$ 7.4) and delta ionized calcium

Following formula was used to calculate corrected ionized calcium (7).

Corrected ionized calcium $=$ Measured ionized calcium $\times[1-0.53 \times(7.4-$ actual $\mathrm{pH})]$

Delta ionized calcium is the difference between ionized calcium and calculated ionized calcium at $\mathrm{pH}$ 7.4

\section{Statistical analysis}

The statistical analysis was performed using Statistical Package for Social Science program (version 16.0; SPSS Inc., Chicago, IL). In the present observational study 6 to 15 (Average 10) successive readings of $A B G$ were noted for each patient. For the descriptive analysis, continuous variables were described as medians with interquartile ranges (IQRs) and categorical variables as percentages and frequencies. Spearman correlation test was done for calculation of correlation between $\mathrm{pH}$ and other ABG parameters. The test with $p$ value $<0.05$ was considered statistically significant.

\section{Results}

Demographic and clinical characteristics of SARS-CoV-2 patients are summarized in Table I. On initial hospital evaluation, median levels of total calcium, total proteins, albumin and NLR ratio was 1.98 $\mathrm{mmol} / \mathrm{L}$ (1.64-2.34), $67 \mathrm{~g} / \mathrm{L}$ (58-74), $26 \mathrm{~g} / \mathrm{L}$ (15.50-35.50) and 8.7 (6.5-29.5) respectively. With median value of $1.98 \mathrm{mmol} / \mathrm{L}$ all the patients were found to be hypocalcemic. Normal levels of serum proteins though on lower side were observed with median value $67 \mathrm{~g} / \mathrm{L}$.

All the patients also showed Hypoalbuminemia with median value of $26 \mathrm{~g} / \mathrm{L}$. Whereas, NLR the ratio of absolute count of neutrophil to lymphocyte with median level 8.7 was also calculated as a stress factor in clinical ICU practice.

Among the total critically ill patients $65 \%$ were males. Fourteen (82\%) out of seventeen patients were having comorbidities i.e. $41 \%$ were diabetic, $6 \%$ were hypertensive whereas $35 \%$ were found to be both diabetic and hypertensive. 18\% were found to be having no comorbidity. Out of seventeen patients, seven (41\%) could not survive. In non-survivors T2DM (86\%) was the most common comorbidity followed by HTN (14\%). Initially, for the observations of acid-base imbalance $53 \%$ were suffering with mixed disorder of acid-base balance (respiratory alkalosis and metabolic acidosis), $41 \%$ with respiratory alkalosis and $6 \%$ with respiratory acidosis. After monitoring 6 to 15 successive readings of the $A B G$ samples for each patient we analyzed a total of 170 samples for which median (IQR) was calculated. For $\mathrm{pH}$ it was 7.43
(7.29-7.56), for $\mathrm{pCO}_{2} 33.6 \mathrm{~mm} / \mathrm{Hg}(14.05-53.97)$, for $\mathrm{HCO}_{3}$ and $\mathrm{iCa} 23.1 \mathrm{mmol} / \mathrm{L}(13-32.79)$ and $0.86 \mathrm{mmol} / \mathrm{L}(0.05-1.57)$ respectively and for $\mathrm{O}_{2}$ saturation $95.3 \%(85.2-105.2)$.

Table II revealed percentage occurrence of abnormal levels of ABG parameters of SARS-CoV-2 patients in which low levels of ionized calcium was $98 \%$ as compared to abnormal levels of $\mathrm{pH}$ being $40 \%, \mathrm{pCO}_{2}$ being $52 \%, \mathrm{HCO}_{3}$ being $58 \%$ and low saturation of oxygen being $46 \%$.

Table I Demographic and clinical characteristics of SARSCoV-2 patients.

\begin{tabular}{|c|c|}
\hline Parameter & Median (IQR) or N (\%) \\
\hline Age, years $(n=17)$ & $62(31.5-83.5)$ \\
\hline Male $(n=17)$ & $11(65 \%)$ \\
\hline Female $(n=17)$ & $6(35 \%)$ \\
\hline $\begin{array}{l}\text { With Comorbidities } \\
\text { (HTN, T2DM) } \\
\text { (T2DM) } \\
\text { (HTN) } \\
\text { No comorbidity }\end{array}$ & $\begin{array}{l}14(82 \%) \\
6(35 \%) \\
7(41 \%) \\
1(6 \%) \\
3(18 \%)\end{array}$ \\
\hline $\begin{array}{l}\text { Acid Base Imbalance } \\
\text { Respiratory Alkalosis } \\
\text { Respiratory Acidosis } \\
\text { Mixed disorder }\end{array}$ & $\begin{array}{l}7(41 \%) \\
1(6 \%) \\
9(53 \%)\end{array}$ \\
\hline $\begin{array}{l}\text { Non survivors } \\
\text { (T2DM) } \\
\text { (HTN) }\end{array}$ & $\begin{array}{l}7(41 \%) \\
6(86 \%) \\
1(14 \%)\end{array}$ \\
\hline Total Calcium, mmol/L ( $\mathrm{n}=17)$ & $1.98(1.64-2.34)$ \\
\hline Total Protein, $\mathrm{g} / \mathrm{L}(\mathrm{n}=17)$ & $67(58-74)$ \\
\hline Serum Albumin, $\mathrm{g} / \mathrm{L}(\mathrm{n}=17)$ & $26(15.50-35.50)$ \\
\hline $\operatorname{NLR}(n=17)$ & $8.7(6.5-29.5)$ \\
\hline $\mathrm{pH}(\mathrm{n}=170)$ & $7.43(7.29-7.56)$ \\
\hline $\mathrm{pCO}_{2}, \mathrm{mmHg}(\mathrm{n}=170)$ & $33.6(14.05-53.97)$ \\
\hline $\mathrm{HCO}_{3}, \mathrm{mmol} / \mathrm{L}(\mathrm{n}=170)$ & $23.1(13-32.79)$ \\
\hline $\mathrm{O}_{2}$, sat $\%(n=170)$ & $95.3(85.2-105.2)$ \\
\hline $\begin{array}{l}\text { lonized Calcium, } \mathrm{mmol} / \mathrm{L} \\
(\mathrm{n}=170)\end{array}$ & $0.86(0.05-1.57)$ \\
\hline
\end{tabular}

HTN - hypertension; DMT2 - diabetes mellitus type 2; NLR neutrophil-to-lymphocyte ratio; $\mathrm{pCO}_{2}$ - partial pressure of carbon dioxide; $\mathrm{HCO}_{3}$ - bicarbonate ion; $\mathrm{O}_{2}$ sat - oxygen saturation

Table II Percentage occurrence of abnormal levels of ABG parameters in SARS-CoV-2 patients.

\begin{tabular}{|l|c|}
\hline Parameter & Readings $\mathrm{n}=170(\%)$ \\
\hline $\mathrm{pH}$ & $68(40)$ \\
\hline $\mathrm{pCO}_{2}$ & $88(51.8)$ \\
\hline $\mathrm{HCO}_{3}$ & $99(58.2)$ \\
\hline $\mathrm{O}_{2}$ saturation & $78(45.9)$ \\
\hline lonized Calcium & $167(98.2)$ \\
\hline
\end{tabular}


Table III depicts Spearman correlation to see the association of $\mathrm{pH}$ with other parameters of $\mathrm{ABG}$. $\mathrm{A}$ strong negative correlation was observed between $\mathrm{pH}$ and $\mathrm{pCO}_{2}$ (Figure 1) and a marginal negative correlation were observed between $\mathrm{pH}$ and ionized calcium (Figure 2). No association was found between $\mathrm{pH}$ and $\mathrm{O}_{2}$ saturation (Figure 3 ). Whereas, a strong positive correlation was observed between $\mathrm{pH}$ and $\mathrm{HCO}_{3}$ (Figure 4) and between $\mathrm{pH}$ and delta ionized calcium

Table III Spearman correlation of $\mathrm{pH}$ with $\mathrm{pCO}_{2}, \mathrm{HCO}_{3}$, ionized calcium and $\mathrm{O}_{2}$ sat in SARS-CoV-2 patients.

\begin{tabular}{|c|c|c|}
\hline Parameter & \multicolumn{2}{|c|}{ Patients with SARS-CoV-2 $\mathrm{pH}$} \\
\hline & $\mathrm{r}_{\mathrm{s}}$ & $\mathrm{p}$ value \\
\hline $\mathrm{pCO}_{2}$ & -0.335 & $<0.001^{*}$ \\
\hline $\mathrm{HCO}_{3}$ & 0.399 & $<0.001^{*}$ \\
\hline lonized Calcium & -0.151 & $0.048^{*}$ \\
\hline $\mathrm{O}_{2}$ saturation & 0.015 & 0.847 \\
\hline Delta ionized calcium & 0.213 & $0.005^{*}$ \\
\hline
\end{tabular}

${ }^{*} \mathrm{p}<0.05$ considered statistically significant. $r$ - Spearman correlation

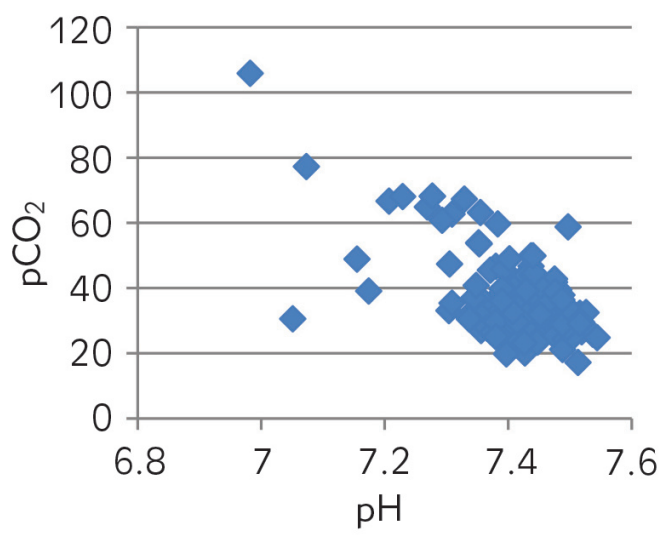

Figure $1 \mathrm{pH}$ vs $\mathrm{pCO}_{2}$.

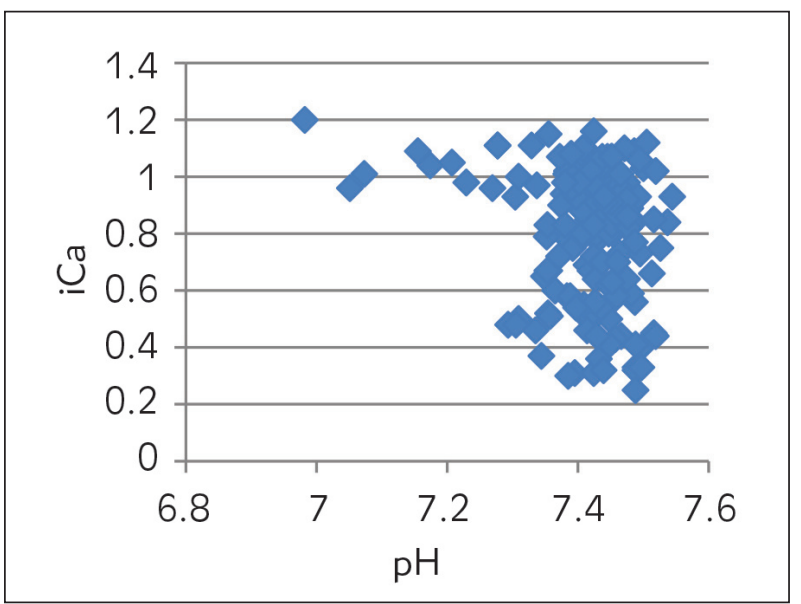

Figure $2 \mathrm{pH}$ vs ionized calcium (iCa).

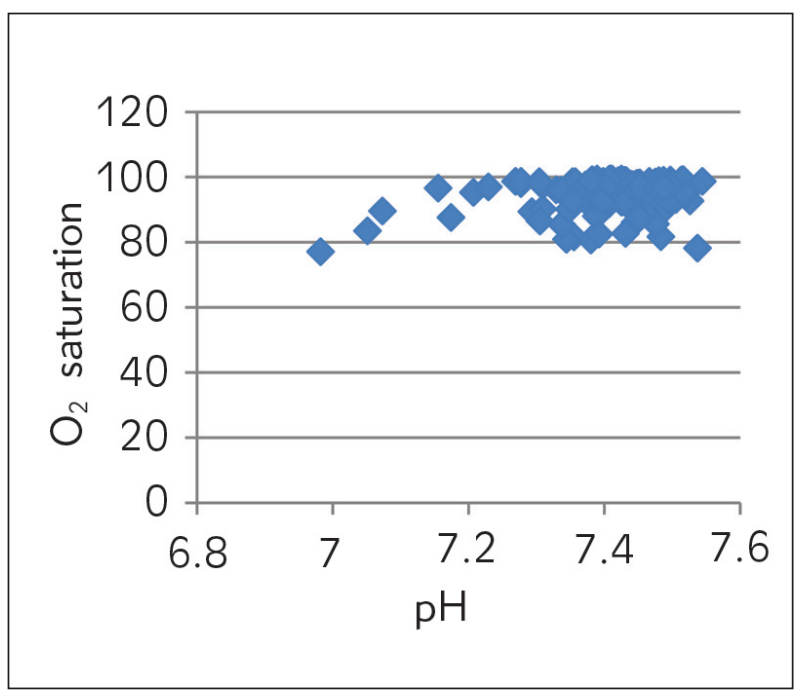

Figure $3 \mathrm{pH}$ vs $\mathrm{O}_{2}$ saturation.

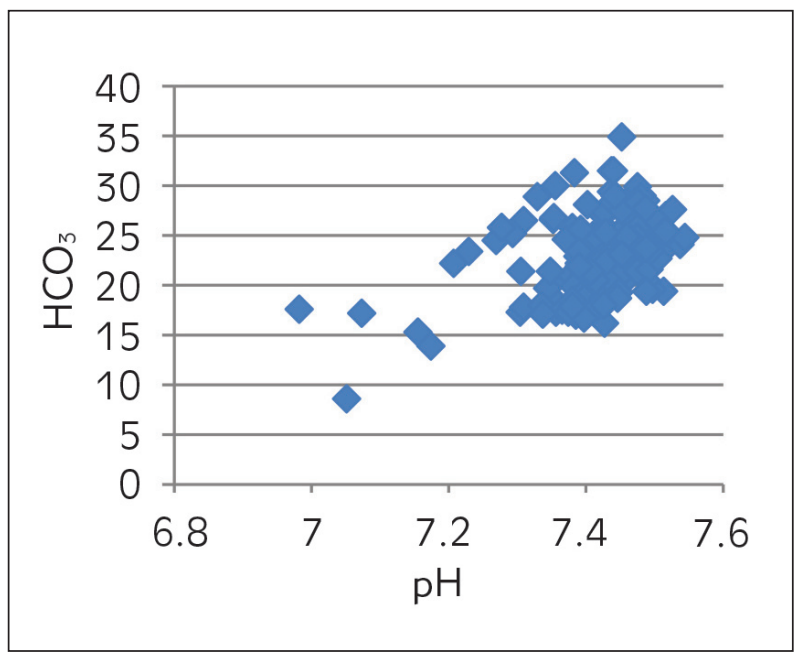

Figure $4 \mathrm{pH}$ vs $\mathrm{HCO}_{3}$.

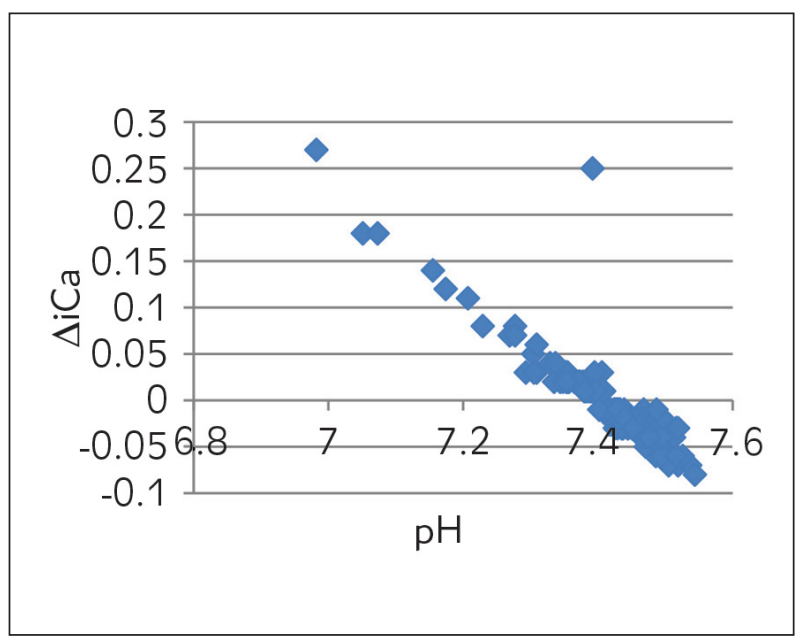

Figure $5 \mathrm{pH}$ vs delta ionized calcium ( $\Delta \mathrm{iCa}$ ). 
(Figure 5). Delta ionized calcium is the difference between ionized calcium and calculated ionized calcium at $\mathrm{pH}$ 7.4. Figure 5 shows both positive (for acidic) and negative (for alkalosis) correlation for $\mathrm{pH}$ and delta ionized calcium. Since, our number of cases was mostly of alkalosis (41\%) and mixed disorder $(53 \%)$ as compared to acidosis $(6 \%)$ the graph depicts more of negative correlation.

\section{Discussion}

A low level of calcium is a common laboratory abnormality in viral infection and pneumonia (8). Previous studies reported that calcium played a vital role in viral infections and replicative mechanisms of SARS-CoV, MERS-CoV and Ebola virus. Calcium ions directly interacted with fusion peptides of these viruses promoting their replication $(9,10)$. Hypocalcemia is a common phenomenon among critically ill patients, its prevalence ranges from $15 \%$ to $88 \%$ in adults (11). Similar to recent study by Zhou et al. (12) our study revealed hypocalcemia in all cases regardless of severity of their condition in the early stage of viral infection. Recently, Filippo et al. (13) observed $80 \%$ hypocalcemic patients in their study.

Considering age factor $59 \%$ of our patients were older than 60 years. Median age of the studied patients was 62 years old which suggested that aged people were more susceptible to severe COVID-19. In another study by Liu et al. (14) $63.6 \%$ of their COVID-19 patients were also of older age ( $>65$ years). Age factor does affect the recovery capacity of a person at the later stages of infection because the liver and kidney function of an individual declines as age advances leading to decrease in intestinal calcium absorption due to low levels of 25- hydroxy cholecalciferol. Similarly, we observed in our study, that the severe critically ill patients who could not survive were older ( $>60$ years) in age.

In our present study among the non-survivors T2DM (86\%) was the most common comorbidity. In Diabetes Mellitus secretion of Parathyroid Hormone (PTH) declines, resulting in decrease disrupted calcium homeostasis that is cellular calcium depletion occurs. PTH stimulates calcitriol (1,25 dihydroxy cholecalciferol), which regulates calcium homeostasis in the body. Calcitriol induced $\mathrm{Ca}^{2+}$ signals (oscillations) regulate insulin secretion from the pancreatic cells $(15,16)$. Thus, the rapid increase in intracellular $\mathrm{Ca}^{2+}$ triggers insulin release.

The perception that acid base imbalance in diabetes is confined to metabolic acidosis is also challenged by our results. The most common disturbance observed was mixed disorder of acid-base balance present in 9 patients. Respiratory disturbance predominantly respiratory alkalosis was present in 7 patients whereas, only 1 patient suffered with respiratory acidosis.

Calcium is predominantly bound to albumin. Almost $30-55 \%$ in the plasma and a decrease in serum albumin will also cause hypocalcemia. Ionized calcium binds to negatively charged sites on protein molecules. Therefore, Hypoalbuminemia is associated with Pseudohypocalcemia which is reduction in total calcium concentration even though there are normal iCa levels (17).

To sustain normal organ function calcium homeostasis has to be maintained. Changes in intracellular calcium homeostasis can also promote the activation of inflammatory pathways leading to increase in tumor necrosis factor (TNF) and IL-6 (18, 19). In addition, hypoxia of tissue and organ induces cell membrane damage resulting in calcium influx (14).

Chernow et al. (20) in their study demonstrated that hypocalcemia was associated with prolonged stay in ICU and increased mortality, similar to our study, in which $41 \%$ were non-survivors, with stay in ICU more than 5 days. Moreover, poor prognosis observed in hypocalcemic patients with severe SARS-CoV-2 was similar to many recent studies (14). Similar to our observations, some authors also identified hypocalcemia as a relevant and independent risk factor for worse clinical outcome, associated with higher mortality in hospitalized and critically ill patients admitted in ICU $(14,21-23)$. Though our results showed marginal significant correlation of $\mathrm{pH}$ and $\mathrm{iCa}$ as such but strong correlation between $\mathrm{pH}$ and delta iCa cannot be ignored too. Moreover, 98\% prevalence of low levels of $\mathrm{iCa}$ as compared to other parameters of $\mathrm{ABG}$ is also worth mentioning.

\section{Limitation}

The main limitation of our study is that the sample size was relatively small. We could only proceed with the samples from patients admitted from October to December. Larger studies are needed to confirm our findings. Possibility of bacterial-infection also could not be ruled out because of high NLR ratio in these studied SARS-CoV-2 patients. We consider that additional studies are required to support these findings.

\section{Conclusion}

Our study suggests that ABG analysis acts as a momentous indicator for critically ill patients admitted in Intensive Care Unit (ICU). Estimation of iCa in this critical care setting acts as a distinctive biochemical feature of SARS-CoV-2 disease, as an initial assessment tool, for hypocalcemia, has a potential impact on its severity. It is also suggested that ionized calcium- the physiologically active component of total calcium should be preferred as routine method for determining the level of calcium in all patients. Moreover, $\mathrm{iCa}$ is also easy to measure (within 15 to 20 minutes) making clinicians in identifying severe patients at initial hospital valuation. Hypocalcemia represents a novel prospective treatment goal worth to be treated at the earliest for improvements in patient care. 
Acknowledgments. The authors are grateful to Professor Malkinder Singh, Department of English of Khalsa College Amritsar for vetting the paper with respect to grammatical mistakes

\section{References}

1. Clinical Management Protocol: COVID-19. https://www. mohfw.gov.in/pdf//2020 version 5.

2. Clinical Management COVID-19Interim guidance WHO/2019-nCoV/clinical/2020.5.

3. Zhu N, Zhang D, Wang W, Li X, Yang B, Song J, et al. A Novel Coronavirus from Patients with Pneumonia in China, 2019. N Engl J Med 2020; 382: 727-33.

4. Chan JFW, Yuan S, Kok KH, To KKW, Chu H, Yang J, et al. A familial cluster of pneumonia associated with the 2019 novel coronavirus indicating person-to-person transmission: a study of a family cluster. Lancet 2020; 395: 514-23. https://doi.org/10.1016/S01406736(20)30154-9.

5. Lingeswaran M, Goyal T, Ghosh R, et al. Inflammation, immunity and immunogenetics in COVID-19: a narrative review. Ind J Clin Biochem 2020; 35: 260-73. https://doi.org/10.1007/s12291- 020-00897-3.

6. Johnson KD, Harris C, Cain JK, Hummer C, Goyal H, Perisetti A. Pulmonary and Extra-Pulmonary Clinical Manifestations of COVID-19. Front Med 2020; 7: 526. https://doi.org/10.3389/fmed.2020.00526.

7. Thode J, Holmegaard SN, Transbøl I, Fogh-Andersen N, Siggaard-Andersen O. Adjusted ionized calcium (at pH 7.4) and actual ionized calcium (at actual $\mathrm{pH}$ ) in capillary blood compared for clinical evaluation of patients with disorders of calcium metabolism. Clin Chem 1990; 36: 541-4.

8. Sankaran RT, Mattana J, Pollack S, Bhat P, Ahuja T, Patel $A$ et al. Laboratory abnormalities in patients with bacterial pneumonia. Chest 1997; 111: 595-600.

9. Letelier P, Encina N, Morales P, Riffo A, Silva H, Riquelme I, Guzmán N. Role of biochemical markers in the monitoring of COVID-19 patients. J Med Biochem 2021; 40(2): 115-28.

10. Nathan L, Lai AL, Millet JK, Straus MR, Freed JH, Whittaker GR, et al. Calcium ions directly interact with the Ebola virus fusion peptide to promote structure function changes that enhance infection. ACS Infect Dis 2020; 6: 250-60.

11. Zivin JR, Gooley T, Zager RA, Ryan MJ. Hypocalcemia: A pervasive metabolic abnormality in the critically ill. Am J Kidney Dis 2001; 37: 689-98.

12. Zhou X, Chen D, Wang L, Zhao Y, Wei L, Chen $Z$, et al. Low serum calcium: a new important indicator of COVID-19 patients from mild/moderate to severe/critical. Bioscience Reports 2020; 40: BSR20202690. https://doi.org/10.1042/BSR20202690

13. Filippo LD, Formenti AM, Doga M, Frara S, RovereQuerini P, Bosi E, et al. Hypocalcemia is a distinctive bio-

\section{Conflict of interest statement}

All the authors declare that they have no conflict of interest in this work.

chemical feature of hospitalized COVID-19 patients. Endocrine 2020 doi: 10.1007/s12020-020-025419 [Epub ahead of print]

14. Liu J, Han P, Wu J, Gong J, Tian D. Prevalence and predictive value of hypocalcemia in severe COVID-19 patients. J Infect Public Health 2020; 13: 1224-8. https://doi.org/10.1016/j. jiph.2020.05.029

15. Seida JC, Mitri J, Colmers IN, Majumdar SR, Davidson $M B, E d w a r d s A L$, et al. Clinical review: Effect of vitamin D3 supplementation on improving glucose homeostasis and preventing diabetes: a systematic review and metaanalysis. J Clin Endocrinol Metab 2014; 99: 3551-60.

16. Sergeev IN, Rhoten WB. 1, 25-Dihydroxyvitamin D3 evokes oscillations of intracellular calcium in a pancreatic beta-cell line. Endocrinology 1995; 136: 2852-61.

17. Liamis G, Liberopoulos E, Barkas F, Elisaf M. Diabetes mellitus and electrolyte disorders. World J Clin Cases 2014; 2: 488-96.

18. Nieto-Torres JL, DeDiego ML, Verdia-Baguena C, Jimenez-Guardeño JM, Regla-Nava JA, FernandezDelgado $R$, et al. Severe acute respiratory syndrome coronavirus envelope protein ion channel activity promotes virus fitness and pathogenesis. PLoS Pathog 2014; 10: e1004077, https://doi.org/10.1371/journal.ppat.1004077.

19. Nieto-Torres JL, Verdia-Baguena C, Jimenez-Guardeno JM, Regla-Nava JA, Castaño-Rodriguez C, FernandezDelgado $R$, et al. Severe acute respiratory syndrome coronavirus $\mathrm{E}$ protein transports calcium ions and activates the NLRP3 inflammasome. Virology 2015; 485: 330-9. https://doi.org/10.1016/j.virol.2015.08.010.

20. Chernow B, Zaloga G, McFadden E, Clapper H, Kotler $M$, et al. Hypocalcemia in critically ill patients. Crit Care Med 1982; 10: 848-51.

21. Filippo LD, Formenti $A M$, Rovere-Querini $P$, Cariucci $M$, Conte C, Ciceri F, et al. Hypocalcemia is highly prevalent and predicts hospitalization in patients with COVID-19. Endocrine 2020; 68: 475-8.

22. Sun JK, Zhang WH, Zou L, Liu Y, Lie JJ, Kan XH, et al. Serum calcium as a biomarker of clinical severity and prognosis in patients with coronavirus disease 2019. Aging 2020; 12: 11287-95. https://doi.org/ 10.18632/ aging. 103526

23. Akirov A, Gorshtein A, Shraga-Slutzky I, Shimon I. Calcium levels on admission and before discharge are associated with mortality risk in hospitalized patients. Endocrine 2017; 57: 344-51. 